So while there is as yet no clear understanding of the factors controlling liver regeneration, it seems likely to be a multifactorial process with hormone changes playing a major part. Purification of the hepatic regenerative stimulator substance could possibly be of clinical value for increasing the regenerative response in some diseases.

${ }^{1}$ Higgins GM, Anderson RM. Experimental pathology of liver : restoration of liver of white rats following partial surgical removal. Archives of Pathology $1931 ; 12: 186-202$.

${ }^{2}$ Lin T-Y, Lee C-S, Chen C-C, Liau K-Y, Lin W-S-J. Regeneration of human liver after hepatic lobectomy studies by repeated liver scanning and repeated needle biopsy. Ann Surg 1979;190:48-53.

${ }^{3}$ Williams R, Hughes RD, Cochrane AMG, Ellis WR, Murray-Lyon IM. Studies on plasma cytotoxicity and liver regeneration in fulminant hepatic failure. Ciba Found Symp 1978; No 55:299-305.

4 Leduc EH. Regeneration of the liver. IIc. Mechanisms controlling liver regeneration. In: Rouiller C, ed. The liver: morphology, biochemistry, physiology. Vol 2. New York: Academic Press, 1964:69-76.

5 Terblanche J, Starzl TE. Hepatic regeneration: implications in fulminant hepatic failure. Int $\mathcal{F}$ Artif Organs 1979;2:49-52.

${ }^{6}$ Leffert H, Alexander NM, Faloona G, Rubalcava B, Unger R. Specific endocrine and hormonal receptor changes associated with liver regeneration in adult rats. Proc Natl Acad Sci USA 1975;72:4033-6.

7 Terblanche J, Porter KA, Starzl TE, Moore J, Patzelt L, Hayashida N. Stimulation of hepatic regeneration after partial hepatectomy by infusion of a cytosol extract from regenerating dog liver. Surg Gynecol Obstet $1980 ; 151: 538-44$.

${ }^{8}$ Goldberg M, Strecker W, Feeny D, Ruhenstroth-Bauer G. Evidence for and characterisation of a liver cell proliferation factor from blood plasma of partially hepatectomised rats. Horm Metab Res 1980 ;12:94-6.

${ }^{9}$ Miura Y, Fukui N. Prostaglandins as possible triggers for liver regeneration after partial hepatectomy-review. Cell Mol Biol 1979;25:179-84.

\section{Patient participation: more pipedream than practice?}

Are those enthusiasts who want to spread the idea of patient participation groups in general practice getting their message across to the right people? To judge by a recent conference at the King's Fund Centre it seems not. Representatives of community health councils, area health authorities, the press, and students and lecturers were more in evidence than general practitioners and patients. Moreover, no good evidence was produced that the groups are beneficial, and some people had unrealistic expectations about what they might achieve.

It is now eight years since the first patient participation group was started, and there are still only 32-a drop in the ocean when there are nearly 11000 practices in Britain. Most have been started not by patients but by doctors, and one reason there are so few may be that many general practitioners have not heard of the idea: thus 10 of 15 general practitioners in the north west of England who were responsible for training groups of doctors had not heard of patient participation groups. ${ }^{1}$ Groups have started up to meet the needs of their particular practices and do not conform to any particular pattern. Health centres seem to have the right conditions, but nobody knows why none flourish in single-handed practices. Perhaps a doctor practising alone is more likely to build up close relationships with his patients, and only those who work in and attend large health centres feel the need for a structured group to encourage communication. Nor does anyone know what patient participation groups achieve or even try to achieve. The aims of some are very broad: their accomplishments include helping doctors; looking at how the services are used-for example, whether it is practicable to have an antenatal clinic at $1 \mathrm{pm}$ for working mothers; organising car services to surgeries in areas with poor public transport; and planning health education activities. But they seem unlikely to achieve anything as ambitious as changingw the way that doctors behave in individual consultations. Thes conference heard several speakers argue for better communica $-\widehat{\mathbb{Q}}$ tion between doctors and individual patients, but nobody made it clear what patient participation groups can do about this.

Understandably community health councils are interested in what patient participation groups are doing and want tom work more closely with them nationally and locally. But the? health councils cover large geographical areas and are concerned with hundreds of thousands of patients, while the main virtue of patient participation groups is that they work locally. Patients work together with general practitioners and other health staff to improve the services for their own $\mathbb{\Phi}$ "community" in their own practice. It is surely human nature to want to focus on narrow personal interests, but if the idea of patient participation really caught on in general practice. the benefit to the larger "community" might be great. The $\overrightarrow{\vec{\omega}}$ health councils must not expect too much too soon.

So should every practice have a patient participation group ? Those who have successful groups seem to enjoy them andiN be convinced of their worth, but some groups have faded? away and some practices have found it impossible to start them. Also no one has produced convincing evidence of $\varnothing$ benefit. Nevertheless, Dr John Horder, president of the $\vec{\oplus}$ Royal College of General Practitioners, was convinced of their worth, advocating at the conference that all trainees in음 general practice should learn about them and going on to say $N$ that this should be added to the college's priorities of prevention and audit.

1 Wood J, Metcalfe DHH. Professional attitudes to patient participation groups: an exploratory study. $\mathcal{F} R$ Coll Gen Pract 1980;30:538-41.

\section{Death of a quango}

Quangos are not popular, so ministers run little risk of disapproval when they kill one off. If the quango is a minor one-a mere subcommittee-its demise is unlikely to be newsworthy. Yet one such subcommittee, which has recently been elimina-io ted by the health and agriculture ministers, deserves at least a decent obituary and perhaps even an attempt to find a way of performing the functions intended for it but never made possible.

The quango in question was the Joint Sub-Committee on $N$ Anti-microbial Substances. It was set up as a result of recom- $\rightarrow$ mendations made by the Swann Committee, ${ }^{1}$ which was created because of concern that the use of antibiotics for promoting $N$ growth in animal husbandry without proper veterinary $N_{\mathcal{E}}$ supervision might produce a great reservoir of antibiotic- $\mathcal{F}$ resistant bacteria which would prejudice the use of antibiotics as therapeutic agents for man and animals. The relevant $\underset{\Phi}{\Phi}$ recommendations were ". . . that one committee should have $\stackrel{+}{+}$ overall responsibility for the whole field of use of antibiotics and related substances whether in man, animals, food preser- $\overrightarrow{\mathbb{D}}$ vation or for other purposes ... and that this committee should $\stackrel{\Phi}{\Phi}$ be empowered to demand, on a basis of confidentiality, such $\frac{\varrho}{0}$ returns as it considers to be necessary." The Swann Report and its recommendations were blessed by the Labour Government in 1969 and by the Conservative Government elected 